\title{
EVALUATION OF THE IMPACT OF THE ECKLONIA MAXIMA EXTRACT ON SELECTED MORPHOLOGICAL FEATURES OF YELLOW PINE, SPRUCE AND THUJA STABBING
}

\author{
Jacek Sosnowski' , Elżbieta Malinowska', Beata Wiśniewska-Kadżajan'1, Kazimierz Jankowski' \\ 1 Department of Grassland and Green Areas Creation. Siedlce University of Natural Sciences and Humanities, \\ B. Prusa 14, 08-110 Siedlce, Poland, e-mail: laki@uph.edu.pl
}

Received: 2016.03.16 Accepted: 2016.06.01 Published: 2016.07.01

\begin{abstract}
The study was focused on the impact of an extract of Ecklonia maxima on selected morphological features of yellow pine (Pinus ponderosa Dougl. ex C. Lawson), prickly spruce (Picea pungens Engelm.) Variety Glauca, thuja (Thuja occidentalis) variety Smaragd. The experiment was established in April 12, 2012 on the forest nursery in Ceranów. April 15, 2013 was introduced research agent in the form of a spraying an aqueous solution extract of Ecklonia maxima with trade name Kelpak SL. Biologically active compounds in the extract are plant hormones: auxin and cytokinin. There were studied increment in plant height, needle length of yellow pine, twigs length in prickly spruce and thuja. The measurements of increment in length of twigs and needles were made in each case on the same, specially marked parts of plants and have carried them on the $27^{\text {th }}$ of each month beginning in May and ending in September. The results were evaluated statistically using the analysis of variance. Medium differentiations were verified by Tukey's test at a significance level $p \leq 0.05$. The study showed that the diversity of traits features in the experiment was depended on the extract, the tree species and the measurement time. The best results after the extract using showed a pine and spruce. Seaweed preparation contributed to increment increased of trees height for in the pine and spruce and the needles length of pine and twigs of spruce. The species showing no reaction to the extract was thuja.
\end{abstract}

Keywords: extract, growth, twigs, needles

\section{INTRODUCTION}

In regard to the presence of mineral compounds and plant hormones [Moller and Smith 1998; 1999; El-Yazied et al. 2012], seaweed extracts help to increase the resistance of plants to disease and stress conditions, thus improving their appearance [Verkleij 1992; El-Yazied et al. 2012; Sosnowski et al. 2013b,c]. The chemical composition of extracts are complex, they have a very high content of organic carbon, polysaccharides and micronutrients and macroelements such as nitrogen, phosphorus and potassium [Crouch and Staden 1993]. According to Khan et al. [2009] and Craigie [2011] their beneficial effect on plant is also associated with existing of vitamins and amino acids in its composition.

Wajahatullah et al. [2009] reported that Ecklonia maxima preparations are treat as a natural fertilizer of new generation. Contrary to mineral fertilizers, bio-components derived from seaweed are biodegradable, non-toxic, harmless to the environment and for the health of humans and animals. Extracts can be therefore may an alternative to a conventional farming systems [Wajahatullah et al. 2009]. Therefore, they are the subject of many scientific studies [Temple and Bomke 1989; Crouch and Staden 1991; Zodape 2001; Pietryga and Matysiak 2003; Matysiak 2005; Matysiak and Adamczewski 2005; Bai et al. 2007; 
Zodapea et al. 2009; Matysiak et al. 2012; ElYazied et al. 2012; Sosnowski et al. 2013 a; b]. In this study they confirmed the beneficial effects on the crop. The authors reported that the extracts accelerate the germination of seeds, increased the amount of biomass produced, stimulating the greenness leaf index SPAD and conductive to the accumulation of some micro- and macronutrients in plant dry matter [Sosnowski et al. 2013a,c]. According to Verkleij [1992] and Galbiattia et al. [2007], effect of the use of seaweed extracts was also improve the plants vigor. So, the use of extracts as natural bio-stimulators, was quickly accepted as horticulture practice [Verkleij 1992; Crouch, Staden 1993].

The aim of the study was to determine the effect of the extract from Ecklonia maxima on the development of selected morphological features of yellow pine, spruce prickly and thuja. The study concerned the volatility of increase of trees height, length of pine needles and twigs of spruce and thuja under the influence of spraying with seaweed extract in particular time periods measured during the growing season of plants.

\section{MATERIALS AND METHODS}

The experiment was established in trees field in Ceranów. In April 2012 into the soil 6 plants of the following species: yellow pine (Pinus ponderosa Dougl. Ex C. Lawson), blue spruce (Picea pungens Engelm.) Variety Glauca, thuja (Thuja occidentalis) variety Smaragd were planted. In the first year the plant were only controlled and inter-rows weeded. In April, 2013 research factor in a form of spraying with an aqueous solution $(100 \mathrm{ml}$ in $400 \mathrm{ml}$ of water) of seaweed extract of Ecklonia maxima (trade name Kelpak SL) was introduced.

Experimental objects were: control (only water spraying), $\mathrm{E}$ - spraying with $20 \mathrm{ml}$ of an aqueous extract on the plant. According manufacturer's extract include: plant hormones, ie. auxin $-11 \mathrm{mg} \cdot \mathrm{dm}^{-3}$, cytokinins $-0.03 \mathrm{mg} \cdot \mathrm{dm}^{-3}$, carbohydrate $-35 \%$, alginic acid $-10 \%$, amino acids $-6 \%$, mannitol $-4 \%$, macronutrients: $\mathrm{N}-3.12 \%$,
$\mathrm{P}_{2} \mathrm{O}_{5}-2.61 \%, \mathrm{~K}_{2} \mathrm{O}-4.71 \%, \mathrm{Ca}-0.25 \%, \mathrm{~S}$ $-3.56 \%, \mathrm{Mg}-0.58 \%$ and microelements: $\mathrm{Fe}-$ 150 ppm, Zn - 70 ppm, Mn - 13 ppm, B - 60 ppm, J-30 ppm.

Tested features include: increase in plant height $(\mathrm{cm})$, the increase in needle length $(\mathrm{cm})$ of yellow pine, twigs increase in the length $(\mathrm{cm})$ of spruce prickly and thuja. The measurements of those features were made each time on the same, specially marked parts of the plant, and it was carried out on 27th day of each month starting in May and ending in September.

The results were evaluated statistically by performing variance analysis. Medium differentiation was verified by Tukey's test at a significance level $\mathrm{p} \leq 0.05$.

Meteorological data for the study area were obtained from Hydro-Meteorological Station in Siedlce. However, in order to determine the temporal variability of meteorological elements and their impact on the course of vegetation, the hydrothermal coefficient of Sielianinov was calculated [Bac et al. 1993].

From the data presented in Table 1 indicate that the most favorable distribution and the amount of precipitation, with the optimal air temperatures in the period of plants growing, were in May and in September. For those months the highest coefficient $(K>2)$ was recorded, which shows the optimal relation of the air temperature to the precipitation. It should also be noted that in August aqueous translates into strong drought $(\mathrm{K}=0.25)$ was in deficit.

\section{RESULTS AND DISCUSSION}

The study showed (tab. 2) that the highest annual increase - mean $51.1 \mathrm{~cm}$, after using of the extract spray occurred in pine. This value was more than $26 \%$ higher than the average height of this species achieved on the control objects. Positive reaction to the preparation showed spruce, which treated with extract achieved more than $22 \%$ higher increases in height. For thuja no effect was observed. This species from 27 May to 27 September on all the objects obtain an average $40 \mathrm{~cm}$ increments.

Table 1. The value of the hydrothermic Sielianinov index $(\mathrm{K})$ in each month of the growing season

\begin{tabular}{|c|c|c|c|c|c|c|c|}
\hline \multirow{2}{*}{ Year } & \multicolumn{7}{|c|}{ Month } \\
\cline { 2 - 9 } & IV & V & VI & VII & VIII & IX & X \\
\hline 2013 & 1.60 & 2.20 & 1.80 & 1.50 & 0.25 & 2.70 & 1.22 \\
\hline
\end{tabular}

$\mathrm{K}<0.5$ - serve drought; $0.51-0.69$ - drought; $0.70-0.99$ - weak drought; $\mathrm{K}>1$ - no drought 
Table 2. The annual increment of trees, height depending on the species and Ecklonia maxima extract

\begin{tabular}{|c|c|c|c|}
\hline \multirow{2}{*}{ Species } & \multicolumn{2}{|c|}{ Factor } & \multirow{2}{*}{ Mean } \\
\hline & Control & Extract & \\
\hline Pinus ponderosa Dougl. ex C. Lawson & $37.8^{\mathrm{Ab}}$ & $51.1^{\text {Aa }}$ & $44.5^{\mathrm{A}}$ \\
\hline Picea pungens Engelm & $24.7^{\mathrm{Bb}}$ & $31.9^{\mathrm{Ba}}$ & $28.2^{\mathrm{B}}$ \\
\hline Thuja occidentalis & $40.4^{\mathrm{Aa}}$ & $40.3^{\mathrm{Aa}}$ & $40.4^{\mathrm{A}}$ \\
\hline Mean & $34.3^{b}$ & $41.1^{\mathrm{a}}$ & \\
\hline
\end{tabular}

Means in lines marked with the same small letters do not differ significantly

Means in columns marked with the same capital letters do not differ significantly

The study also showed significant differences in the high increase of studied trees species in different dates of measurement (Table 3). The biggest monthly increases in height (mean $18.3 \mathrm{~cm}$ ), regardless of the species and the extract was reported in June. Quite a lot of growing trees were also observed in May (mean $7.67 \mathrm{~cm}$ ) and in July (mean $6.72 \mathrm{~cm}$ ). The smallest increases occurred in September (mean $1.17 \mathrm{~cm}$ ). It should be noted, however, that regardless of the species, at each measurement time, trees treated with the extract, obtained the higher increase to control. On average, the difference in the measurement was $22 \%$.

Data presented in Figure 1 showed, that the spraying of trees with Ecklonia maxima extract also caused up to $0.95 \mathrm{~cm}$ increase in the annual regrowth of the length of pine needles and 2.15 $\mathrm{cm}$ increase in the length of spruce twigs. Also, the value of length increments of thuja twigs on the objects with extract was about $0.80 \mathrm{~cm}$ higher than the values obtained for control, but it was not confirmed statistically.
On the other hand, analyzing the value of length increment of pine needle in particular months (Table 4), it is noted that the greatest differences in mean values of this feature between control object $(\mathrm{Q})$ and the objects with factors $(\mathrm{E})$ was observed in August. Perhaps on this effect the course of the weather conditions in this month has directly influenced. High daily temperatures in sunny and dry weather favored to plants increments especially after a period with heavy precipitation, as indicated by the values of Sielianinov index in May, June and July (Table 1). The extract has also contributed to an increase in increments of spruce stinging twigs (Table 5). An average, regardless of the date of measurement, increase in the plants sprayed with extract was about $45 \%$ higher than on the control object. Noteworthy is the fact that as time goes from spraying, the difference between the value in increments between factor objects and control object has decreased, and since July it has ceased to be statistically significant. Statistical analysis, regardless of the date

Table 3. Increment of trees height in particular measurement time in depending on the species and the extract of Ecklonia maxima

\begin{tabular}{|c|c|c|c|c|c|c|c|}
\hline \multirow{2}{*}{ Species } & \multirow{2}{*}{ Factor } & \multicolumn{5}{|c|}{ The measurements term (month) } & \multirow{2}{*}{ Mean } \\
\hline & & 0.5 & 0.6 & 0.7 & 0.8 & 0.9 & \\
\hline \multirow{3}{*}{\begin{tabular}{|l} 
Pinus \\
ponderosa \\
Dougl. ex C. \\
Lawson
\end{tabular}} & Control & $12.3^{\mathrm{Ab}}$ & $20.7^{\mathrm{Ba}}$ & $3.12^{\mathrm{Bc}}$ & $1.09^{\mathrm{Bc}}$ & $0.57^{\mathrm{Bc}}$ & $7.56^{\mathrm{B}}$ \\
\hline & Extract & $13.8^{\mathrm{Ab}}$ & $23.2^{\mathrm{Aa}}$ & $6.10^{\mathrm{Ac}}$ & $4.34^{\mathrm{Ac}}$ & $3.61^{\mathrm{Ac}}$ & $10.2^{\mathrm{A}}$ \\
\hline & Mean & $13.1^{\mathrm{b}}$ & $22.0^{\mathrm{a}}$ & $4.61^{c}$ & $2.71^{c}$ & $2.09^{c}$ & $8.90^{\mathrm{A}}$ \\
\hline \multirow{3}{*}{$\begin{array}{l}\text { Picea pungens } \\
\text { Engelm }\end{array}$} & Control & $6.24^{\mathrm{Ab}}$ & $15.7^{\mathrm{Ba}}$ & $1.18^{\mathrm{BC}}$ & $0.93^{\mathrm{AC}}$ & $0.62 \mathrm{Ac}$ & $4.94^{\mathrm{B}}$ \\
\hline & Extract & $7.38^{\mathrm{Ab}}$ & $19.5^{\mathrm{Aa}}$ & $2.59^{A C}$ & $1.47^{\mathrm{AC}}$ & $0.89^{A C}$ & $6.37^{A}$ \\
\hline & Mean & $6.81^{b}$ & $17.6^{\mathrm{a}}$ & $1.89^{c}$ & $1.20^{c}$ & $0.76^{c}$ & $5.65^{\mathrm{C}}$ \\
\hline \multirow{3}{*}{$\begin{array}{l}\text { Thuja } \\
\text { occidentalis }\end{array}$} & Control & $2.47^{\mathrm{Abc}}$ & $16.5^{\mathrm{Aa}}$ & $13.5^{\mathrm{Aa}}$ & $7.09^{\mathrm{Ab}}$ & $0.82^{\mathrm{Ac}}$ & $8.08^{\mathrm{A}}$ \\
\hline & Extract & $3.82^{\mathrm{Abc}}$ & $14.2^{\mathrm{Ba}}$ & $13.8^{\mathrm{Aa}}$ & $8.00^{\mathrm{Ab}}$ & $0.50^{A c}$ & $8.06^{A}$ \\
\hline & Mean & $3.15^{\mathrm{bc}}$ & $15.4^{a}$ & $13,7^{a}$ & $7.55^{\mathrm{b}}$ & $0.66^{c}$ & $8.09^{B}$ \\
\hline \multicolumn{2}{|c|}{ Control } & $7.00^{\mathrm{Ab}}$ & $17.6^{\mathrm{Ba}}$ & $5.93^{\mathrm{Bb}}$ & $3.04^{\mathrm{Bbc}}$ & $0.67^{A c}$ & $6.85^{\mathrm{B}}$ \\
\hline \multicolumn{2}{|c|}{ Extract } & $8.33^{A b}$ & $19.0^{\mathrm{Aa}}$ & $7.50^{\mathrm{Ab}}$ & $4.60^{\mathrm{Abc}}$ & $1.67^{A c}$ & $8.89^{\mathrm{A}}$ \\
\hline \multicolumn{2}{|c|}{ Mean } & $7.67^{b}$ & $18.3^{a}$ & $6.72^{\mathrm{b}}$ & $3.82^{b c}$ & $1.17^{c}$ & \\
\hline
\end{tabular}

Means in lines marked with the same small letters do not differ significantly

Means in columns marked with the same capital letters do not differ significantly 
Table 4. Increment of needle length $(\mathrm{cm})$ of pine in particular measurement time in depended on an extract of Ecklonia maxima

\begin{tabular}{|c|c|c|c|c|c|c|c|}
\hline \multirow{2}{*}{ Species } & \multirow{2}{*}{ Factor } & \multicolumn{5}{|c|}{ The measurements term (month) } & \multirow{2}{*}{ Mean } \\
\hline & & 0.5 & 0.6 & 0.7 & 0.8 & 0.9 & \\
\hline \multirow{3}{*}{$\begin{array}{l}\text { Pinus ponderosa } \\
\text { Dougl. ex C. } \\
\text { Lawson }\end{array}$} & Control & $0.20^{\mathrm{Bab}}$ & $0.30^{\text {Aab }}$ & $0.10^{\mathrm{AC}}$ & $0.45^{\mathrm{Ba}}$ & $0.10^{\mathrm{BC}}$ & $0.23^{\mathrm{B}}$ \\
\hline & Extract & $0.40^{\mathrm{Ab}}$ & $0.40^{\mathrm{Ab}}$ & $0.10^{\mathrm{Ac}}$ & $1.01^{\mathrm{Aa}}$ & $0.20^{\mathrm{Ac}}$ & $0.42^{\mathrm{A}}$ \\
\hline & Mean & $0.20^{c}$ & $0.30^{\mathrm{b}}$ & $0.10^{d}$ & $0.45^{\mathrm{a}}$ & $0.10^{d}$ & \\
\hline
\end{tabular}

Means in lines marked with the same small letters do not differ significantly

Means in columns marked with the same capital letters do not differ significantly

Table 5. Increment of the twigs length $(\mathrm{cm})$ of spruce in particular measurement time in depended on an extract of Ecklonia maxima

\begin{tabular}{|c|c|c|c|c|c|c|c|}
\hline \multirow{2}{*}{ Species } & \multirow{2}{*}{ Factor } & \multicolumn{5}{|c|}{ The measurements term (month) } & \multirow{2}{*}{ Mean } \\
\hline & & 0.5 & 0.6 & 0.7 & 0.8 & 0.9 & \\
\hline \multirow{3}{*}{$\begin{array}{l}\text { Picea pungens } \\
\text { Engelm }\end{array}$} & Control & $2.01^{\mathrm{Ba}}$ & $0.98^{\mathrm{Bb}}$ & $1.02^{\mathrm{Ab}}$ & $0.50^{\mathrm{AC}}$ & $0.20^{\mathrm{AC}}$ & $0.94^{\mathrm{B}}$ \\
\hline & Extract & $3.00^{\mathrm{Aa}}$ & $2.00^{\mathrm{Ab}}$ & $0.93^{\mathrm{AC}}$ & $0.70^{\text {Acd }}$ & $0.23^{\mathrm{Ad}}$ & $1.37^{\mathrm{A}}$ \\
\hline & Mean & $2.50^{\mathrm{a}}$ & $1.49^{b}$ & $0.98^{\mathrm{bc}}$ & $0.60^{c}$ & $0.22^{c}$ & \\
\hline
\end{tabular}

Means in lines marked with the same small letters do not differ significantly

Means in columns marked with the same capital letters do not differ significantly

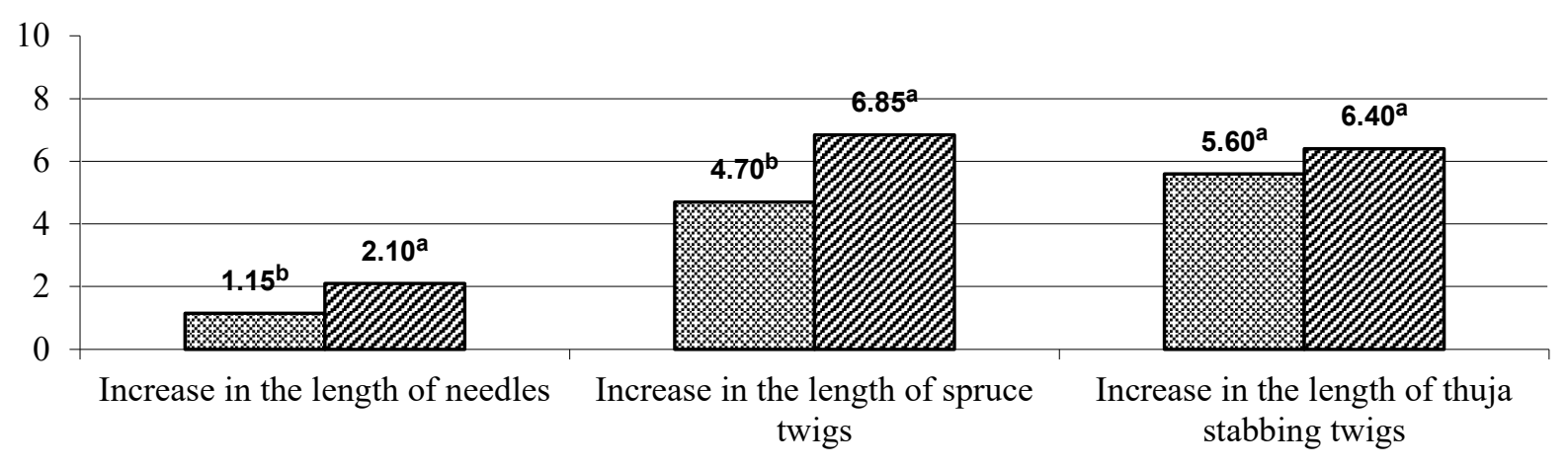

$$
\text { Control } \quad \text { Extract }
$$

Figure 1. The annual increment in the needles length of pine and o the spruce and thuja twigs in depending on the extract of Ecklonia maxima

of measurement, also showed no significant difference in the mean values of thuja twigs growth under the influence of the extract (Tab. 6). Moreover, as the data indicated, in May it a significant decrease in the average value of the characteristics under the influence of experimental factor was reported.

Numerous studies [Verkleij 1992; Zodape 2001; Fornes et al. 2002; Russell, 2002; Pietryga and Matysiak 2003; Matysiak, 2005; Matysiak and Adamczewski 2005; Thirumaran et al. 2009] show that Ecklonia maxima extract can not damage the crops but stimulates some organs to increase of its dimensions. This was confirmed in studies on the reaction of pine, spruce and thuja. In turn, Bai et al. [2007] as a result of foliar ap- plication of algae extracts on plant compared to the control crop obtained the stems longer by $35 \%$ and the roots by about $22 \%$. Similar results were presented by Thevanathan et al. [2005]. Significant impact of biostimulator hormone from seaweed of Ecklonia maxima on the yield of plants describe Pietryga and Matysiak [2003] and Matysiak [2005]. However, from research of Matysiak and Adamczewski [2006] resulted that the plant which most responsive to applied biopreparations was corn. The application of the extract resulted in an increase in the plants yield by over $21 \%$ compared to the control object. The listed studies show differences in response to extract of individual grains. The authors showed that spring cereals react more strongly than win- 
Table 6. Increment of the twigs length $(\mathrm{cm})$ of thuja in particular measurement time in depend on an extract of Ecklonia maxima

\begin{tabular}{|c|c|c|c|c|c|c|c|}
\hline \multirow{2}{*}{ Species } & \multirow{2}{*}{ Factor } & \multicolumn{5}{|c|}{ The measurements term (month) } & \multirow{2}{*}{ Mean } \\
\hline & & 0.5 & 0.6 & 0.7 & 0.8 & 0.9 & \\
\hline \multirow{3}{*}{ Thuja occidentalis } & Control & $2.50^{\mathrm{Aa}}$ & $1.60^{\mathrm{Ab}}$ & $0.10^{\mathrm{Ac}}$ & $1.30^{\mathrm{Ab}}$ & $0.10^{\mathrm{Bc}}$ & $1.12^{\mathrm{A}}$ \\
\hline & Extract & $1.70^{\mathrm{Bab}}$ & $2.00^{\mathrm{Aa}}$ & $0.10^{\mathrm{Ac}}$ & $1.70^{\mathrm{Aab}}$ & $0.90^{A b}$ & $1.28^{\mathrm{A}}$ \\
\hline & Mean & $2.10^{\mathrm{a}}$ & $1.80^{\mathrm{a}}$ & $0.10^{\mathrm{b}}$ & $1.50^{\mathrm{a}}$ & $0.50^{\mathrm{b}}$ & \\
\hline
\end{tabular}

Means in lines marked with the same small letters do not differ significantly

Means in columns marked with the same capital letters do not differ significantly

ter crops. It should be noted, however, that there are also experiments in which there was no significant effect of this type of extracts on plants [De Villiers et al. 1983; Temple and Bomke 1989; Nour et al. 2010; Zodape at al. 2010; Sridhar and Rengas 2011]. Research in most cases, confirming the beneficial effects of the extract on the crop but indicate a greater importance of the application date than the dose [Matysiak et al. 2012]. Further, it was demonstrated [Matysiak and Adamczewski 2005], that species and even varieties of the same species can react differently to the seaweed preparations. This may be explained with the lack of effect of the extract from Ecklonia maxima to increase the height and length of thuja twigs. Some studies [Matysiak and Adamczewski, 2005] showed that greater effects were obtained by plant sprayed with an extract from Monocotyledones. In contrast, species such as white mustard and pea are less responsive to the effects of this preparation.

\section{CONCLUSIONS}

1. The study showed that the reaction of the analyzed trees on sprayed with seaweed extract from Ecklonia maxima depended on the species and the measurement date.

2. The best results after the extract applying were showed by pine and spruce. The total increases in the course of growing on the factor objects in both of these species were on average $24 \%$ higher, compared to the control.

3. The largest increases of plant height, regardless of the extract, was reported in June. Their values, depending on the tree species, ranged from $22 \mathrm{~cm}$ in yellow pine to $15.4 \mathrm{~cm}$ in thuja.

4. Seaweed preparation contributed to regrowth increase in the length of pine needles and spruce twigs.

5. Thuja showed no significant effects on the extract used in the experiment.

\section{REFERENCES}

1. Bac S., Kożmiński C., Rojek M. 1993. Agrometeorologia. PWN, Warszawa, 23-33.

2. Bai N.R., Banu N.R.L. Prakash J.W., Goldi S.J. 2007. Effects of Asparagopsis taxiformis extract on the growth and yield of Phaseolus aureus. Journal of Basci and Applied Biology 1(1), 6-11.

3. Craigie J.S. 2011. Seaweed extract stimuli plant science and agriculture. J Appl. Phycol. 23, 371-393.

4. Crouch I.J., Staden J. 1991. Evidence for rooting factors in a seaweed concentrate prepared from Ecklonia maxima. J Plant Physiol. 137, 319-322.

5. Crouch I.J., Staden J. 1993. Effect of seaweed concentrate from Ecklonia maxima (Osbeck) Papenfuss on Meloidogyne incognita infestation on tomato. J Appl Phycol. 5, 37-43.

6. De Villiers J., Kotze W.A.G, Joubert M. 1983. Effect of seaweed foliar spray on fruit quality and mineral nutrition. The Decidous Fruit Grower 33, 97-101.

7. El-Yazied A., El-Gizawy A.M., Ragab M.I., Hamed E. S. 2012. Effect of seaweed extract and compost treatments on growth, yield and quality of snap bean. Journal of American Science 8(6), 1-20.

8. Fornes F., Sa'nchez-Perales M., Guadiola J.L. 2002. Effect of a seaweed extract on the productivity of 'de Nules' clementine mandarin and navelina orange. Bot Mar 45, 486-489.

9. Galbiattia J.A., Cavalcantea I.H.L., Ribeiroa A.G., Pissarraa T.C.T. 2007. Nitrate and sodium contents on lettuce and drained water as function of fertilizing and irrigation water quality in Brazil. Int. J. Plant Prod. 1, 205-214.

10. Khan W., Rayirath U.P., Subramanian S., Jithesh M.N., Rayorath P., Hodges D.M., Critchley A.T., Craigie J.S., Norrie J., Prithiviraj B. 2009. Seaweed extracts as biostimulants of plant growth and development. Plant Growth Regul. 28, 386-399.

11. Matysiak I., Kaczmarek S. Leszczyńska D. 2012. Influence of liquid seaweed extract of Ecklonia maxima on winter wheat cv Tonacja. Journal of Research and Applications in Agricultural Engineering, 57(4), 44-47. 
12. Matysiak K. 2005. Kelpak - naturalny regulator wzrostu i rozwoju roślin. [W]: „Wybrane zagadnienia ekologiczne we współczesnym rolnictwie. Monografia 2" Red. Z. Zbytek, Przemysłowy Instytut Maszyn Rolniczych, 375, 188-193.

13. Matysiak K., Adamczewski K. 2006. Wpływ bioregulatora Kelpak na plonowanie roślin uprawnych. Progress in Plant Protection / Postępy w Ochronie Roślin 46(2), 102-108.

14. Matysiak K., Adamczewski K. 2005. Ocena działania regulatorów wzrostu w rzepaku ozimym. Prog. Plant Protection/Post.Ochr. Roślin 45, 898-902.

15. Moller M., Smith M.L. 1999. The effect of pruning treatments using seaweed suspensions on the water sensitivity of Barley (Hardeum vulgare L.) caryopses. Annals of Applied Biology 135, 515-522.

16. Moller, M., Smith M.L., 1998. The significance of the mineral component of seaweed suspension on lettuce (Lactuca sativa L.) seedling growth. Journal of Plant Physiology 153, 658-663.

17. Nour K. A. M., Mansour N. T. S., Abd El-Hakim W. M. 2010. Influence of foliar spray with seaweed extracts on growth, setting and yield of tomato during summer season. J. Plant Production, Mansoura University, 1(7), 961-976.

18. Pietryga J., Matysiak K. 2003. Biologiczna ocena bioregulatora wzrostu Kelpak w rzepaku ozimym. Prog. Plant Protection 43, 863-865

19. Russell C.L. 2002. Kelp Based growth stimulants - science or snake oil? Internal Technical Biulletin of Cobbett Pty Ltd.

20. Sosnowski J., Jankowski K., Wiśniewska-Kadźajan B. 2013a. Effect of Kelp SL on the formation of above-ground biomass of Festulolium baunii (K. Richt.) A. Camus, Acta Agrobot. 66, 2, 149-154. DOI:10.5586/aa.2013.031

21. Sosnowski J., Jankowski K., Wiśniewska-Kadżajan B., Jankowska J. 2013b. Effect of different concentrations of Kelpak bioregulator on the formation of above-ground biomass cocksfoot. J. Ecol. Eng. 14(1), 48-52. DOI:10.5604/208139X.1031536

22. Sosnowski J., Jankowski K., WisniewskaKadżajan B., Jankowska J. 2013c. Effect of the Ecklonia maxima extract on selected micro- and macroelements in above-ground biomass of Festulolium baunii (K. Richt.) A. Camus. Polish Journal of Natural Sciences 28(3), 317-326.

23. Sridhar S. Rengasamy R. 2011. Efeect of seaweed liquid fertilizer on the growth, biochemical constituents and yield of Tagetes erecta, under field trial. J. of Phytology 2(6), 61-68.

24. Temple W.D., Bomke A.A. 1989. Effects of kelp (Macrocystis integrifolia and Ecklonia maxima) foliar applications on bean crop growth. Plant Soil $117,85-92$.

25. Thevanathan R. Anjanadutta, Dinamani D.S, Bhavani L.G. 2005. Studies on the impact of application of marine algal manure and liquid fertiliser on the linear growth of the seedlings of some pulses. Seaweed research Utilisation 27(2), 125-133.

26. Thirumaran G., Arumugam M., Arumugam R., Anantharaman P. 2009. Effect of seaweed liquid fertilizer on growth and pigment concentration of Cyamopsis tetrogonolaba (L) Taub. AmericanEurasian Journal of Agronomy 2(2), 50-56.

27. Verkleij F.N. 1992. Seaweed extracts in agriculture and Horticulture. A Review Biological Agriculture and Horticulture 8, 309-324.

28. Wajahatullah K., Usha P.R., Sowmyalakshmi S., Mundaya N.J., Prasanth R., Hodges A. Critchley T., Craigie J.S., Norrie J., Prithiviraj B. 2009. Seaweed extracts as biostimulants of plant growth and development. J Plant Growth Regul. 28, 386-399. DOI 10.1007/s00344-009-9103-x

29. Zodape S.T., 2001. Seaweeds as a biofertilizer. J. Sci. Industrial Res. 60(5), 378-382.

30. Zodape S.T., Mukhopadhyay S., Eswaran K., Reddy M.P., Chikara J. 2010. Enhanced yield and nutritional quality in green gram (Phaseoulus radiata L.) treated with seaweed (Kappaphycus alvarezii) extract. Journal of Scientific \& Industrial Research 69, 468-471.

31. Zodapea S.T., Mukherjeea S., Reddya M.P., Chaudharya D.R. 2009. Effect of Kappaphycus alvarezii (Doty) exsilva. extract on grain quality, yield and some yield components of wheat (Triticum aestivum L.). International Journal of Plant Production 3(2), 97-101. 